\title{
A reporting guide for overviews
}

Correspondence: ccdr-rmtc@phac-aspc.gc.ca

Suggested citation: A reporting guide for overviews. Can Comm Dis Rep 2016;42:179-80. https://doi.org/10.14745/ccdr.v42i09a03

Overviews are useful to explore a new area, summarize the state of evidence on a broad topic, and provide insight into the progression of a body of research. Because evidence in clinical and public health evolves rapidly, an expert summary and assessment can be extremely valuable. For example, what are the challenges in eliminating pediatric HIV infection (1)? Or what is the current evidence regarding prion disease? Prior diseases were once thought to be extremely rare, but have now been linked to a much broader group of protein-misfolding disorders that may be more common than previously thought (2). An overview by an expert in the field can provide a useful introduction to emerging issues as well as a framework to better understand subsequent developments (3).

Overviews are not underdeveloped systematic reviews. Systematic reviews are best for specific topics (4). For example, a systematic review is often used to analyze the evidence on the effectiveness of a specific drug for a specific condition in a specific population. Overviews are best for general topics. A systematic review is research that puts evidence under a microscope; an overview is an evidence-based expert opinion that scans a body of evidence with binoculars.

The potential weakness of an overview is bias. Readers need to be assured that the evidence summarized is fair and accurate, and not inappropriately selective. A multi-database literature search with the support of a research librarian can help address this (5) as will a transparent analysis. The goal of an overview is not to provide the highest level of evidence, but rather to summarize, analyze and edify.

Because we are unaware of any reporting guidelines for an overview paper, the Canada Communicable Disease Report (CCDR) has developed a 16-item checklist based on the literature and best practice in scientific communications. This checklist identifies the need to address a topic in a way that is logical, balanced and insightful, including the consideration of contradictory evidence, strengths and limitations, and potential next steps (Table 1).

An overview is generally 1,500 to 2,000 words in length. As with all submissions, check CCDR's Information for authors, published at the beginning of each volume in January of each year for general manuscript preparation and submission requirements (6).
Table 1: Checklist for overview papers

\begin{tabular}{|c|c|c|}
\hline Reporting item & No. & Description \\
\hline \multicolumn{3}{|l|}{ Title/Abstract } \\
\hline Title & 1 & $\begin{array}{l}\text { Compose a title that includes the } \\
\text { population, condition or primary issue } \\
\text { addressed in the overview. }\end{array}$ \\
\hline Abstract & 2 & $\begin{array}{l}\text { Provide a } 200 \text { to } 250 \text {-word abstract that } \\
\text { identifies the issue, why it is important, } \\
\text { the objective of the overview, key points } \\
\text { and a conclusion. }\end{array}$ \\
\hline \multicolumn{3}{|l|}{ Introduction } \\
\hline Issue identification & 3 & $\begin{array}{l}\text { Identify the topic of the study and why it } \\
\text { is important. }\end{array}$ \\
\hline Rationale for study & 4 & $\begin{array}{l}\text { Identify the rationale for providing an } \\
\text { overview. }\end{array}$ \\
\hline Objective & 5 & $\begin{array}{l}\text { Clearly articulate the objective of the } \\
\text { overview. }\end{array}$ \\
\hline \multicolumn{3}{|l|}{ Scope } \\
\hline Setting/population & 6 & $\begin{array}{l}\text { Describe the setting or populations } \\
\text { identified for the overview. }\end{array}$ \\
\hline Approach & 7 & $\begin{array}{l}\text { Identify any decision points about what } \\
\text { to include or not include in the overview } \\
\text { and the rationale. }\end{array}$ \\
\hline Literature search & 8 & $\begin{array}{l}\text { Identify any literature searches } \\
\text { conducted to address potential bias. }\end{array}$ \\
\hline \multicolumn{3}{|l|}{ Key findings } \\
\hline $\begin{array}{l}\text { Population, time } \\
\text { and place }\end{array}$ & 9 & $\begin{array}{l}\text { When applicable, present the findings in } \\
\text { enough detail to provide a sense of the } \\
\text { population, time and place. }\end{array}$ \\
\hline $\begin{array}{l}\text { Logical, balanced } \\
\text { and insightful } \\
\text { analysis }\end{array}$ & 10 & $\begin{array}{l}\text { Present an analysis that demonstrates } \\
\text { how the overview addresses the } \\
\text { stated objective; is logical, includes } \\
\text { countervailing evidence when indicated } \\
\text { to provide a balanced view, and provides } \\
\text { an expert interpretation of the literature. }\end{array}$ \\
\hline $\begin{array}{l}\text { Supported with } \\
\text { references }\end{array}$ & 11 & $\begin{array}{l}\text { Support assertions and facts with } \\
\text { appropriate references. }\end{array}$ \\
\hline \multicolumn{3}{|l|}{ Discussion } \\
\hline $\begin{array}{l}\text { Summary of key } \\
\text { findings }\end{array}$ & 12 & $\begin{array}{l}\text { Summarize key findings and indicate how } \\
\text { the findings are relevant to the objective } \\
\text { of the study. }\end{array}$ \\
\hline $\begin{array}{l}\text { Comparative } \\
\text { analysis }\end{array}$ & 13 & $\begin{array}{l}\text { Explore corroborative findings and } \\
\text { consider contradictory evidence (if } \\
\text { available). }\end{array}$ \\
\hline $\begin{array}{l}\text { Strengths and } \\
\text { limitations }\end{array}$ & 14 & $\begin{array}{l}\text { Identify the strengths and limitations of } \\
\text { the state of knowledge for the overview } \\
\text { topic. }\end{array}$ \\
\hline Next steps & 15 & $\begin{array}{l}\text { Propose next steps or further areas for } \\
\text { inquiry. }\end{array}$ \\
\hline Conclusion & 16 & $\begin{array}{l}\text { Ensure the conclusion integrates the key } \\
\text { findings and addresses the objective of } \\
\text { the study. }\end{array}$ \\
\hline
\end{tabular}

Abbreviation: No., Number 


\section{References}

1. Luzuriaga K, Mofenson LM. Challenges in the elimination of pediatric HIV-1 infection. N Engl J Med 2016;374:761-770 doi: 10.1056/NEJMra1505256.

2. Cashman NR. Protein misfolding: New opportunities for therapeutics, new public health risk. Can Comm Dis Rep 2015;41:196-199. http://www.phac-aspc.gc.ca/publicat/ ccdr-rmtc/15vol41/dr-rm41-08/ar-03-eng.php.

3. Frontzek K, Lutz MI, Aguzzi A, Kovacs GG, Budka H. Amyloid- $\beta$ pathology and cerebral amyloid angiopathy are frequent in iatrogenic Creutzfeldt-Jakob disease after dural grafting Swiss Med Wkly. 2016;146:w14287.
4. Systematic review reporting guide. Can Comm Dis Rep 2015;41:79-82. http://www.phac-aspc.gc.ca/publicat/ccdrrmtc/15vol41/dr-rm41-04/assets/pdf/15vol41_04-eng.pdf.

5. Rethlefsen $\mathrm{ML}$, Murad MH, Livingston $\mathrm{EH}$. Engaging medical librarians to improve the quality of review articles. JAMA 2014;312(10):999-1000. doi:10.1001/jama.2014.9263.

6. Information for authors. Can Comm Dis Rep 2016;42:20-1. http://www.phac-aspc.gc.ca/publicat/ccdr-rmtc/16vol42/drrm42-9/ar-04-eng.php.

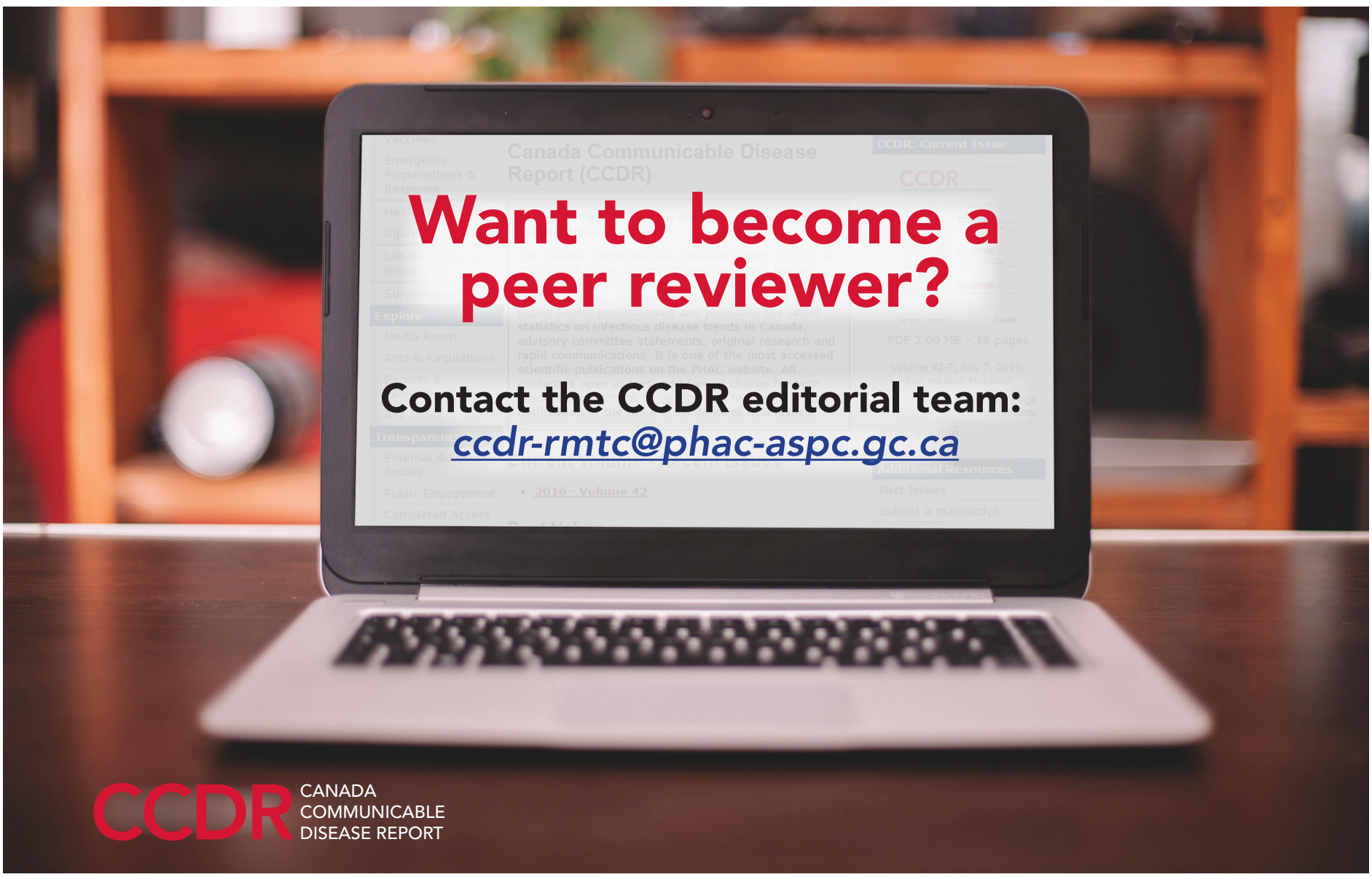

